\title{
Formula One and global road safety
}

Ian Roberts

J R Soc Med 2007; 100:360-362

Formula One, motorist organizations and car makers have manoeuvred themselves into pole position in global road safety politics. The FIA, the governing body of motor sport, has established a Commission for Global Road Safety that aims to set the policy agenda for road safety in poor countries. ${ }^{1}$ Formula One's ability to access and influence leading political figures has undoubtedly raised the profile of road traffic crashes as a global public health crisis, but the policies it promotes are neither the most effective in preventing injury, nor the most environmentally sustainable.

World-wide, road traffic crashes kill about 1.2 million people each year and injure over 50 million. ${ }^{2}$ Most of the injuries are in poor countries and most of the victims are pedestrians and cyclists - and the carnage continues to grow. According to the World Health Organization (WHO), road deaths in poor countries will rise by over $80 \%$ by 2020 . The cost of traffic injuries in low and middle income countries is already estimated at $\$ 65$ billion, more than the total amount they receive in development aid. ${ }^{2}$

The Fédération Internationale de l'Automobile, better known as the FIA, is the governing body of motor sport. ${ }^{3}$ It was set up in 1904 and represents the interests of motoring organizations and car users worldwide. In 2001, it established the FIA Foundation, a charity with the stated aim of 'promoting road safety, environmental protection and sustainable mobility.' Last year, the FIA set up a Commission for Global Road Safety with a remit to 'examine the framework for and level of international cooperation on global road safety and to make policy recommendations.' The Commission is chaired by former UK Defence Secretary, Lord Robertson, and at its inception had eight commissioners, one from each of the G8 group of wealthy nations.

In terms of 'representing the interest of motoring organizations' one could not imagine a more able group of Commissioners. Canada is represented by an Executive Director at General Motors, Japan by a Board Member of the Bridgestone Corporation, the major trans-national tyre maker. Russia is represented by the President of the Russian Automobile Federation and Italy by a former president of

London School of Hygiene \& Tropical Medicine, University of London

Email: lan.Roberts@Ishtm.ac.uk the Automobile Club of Italy. Michael Schumacher represents Germany and France is represented by Gerard Saillant, Deputy President of the FIA Institute, another FIA creation and responsible for the medical aspects of Formula One. The UK Commissioner is the Chief Economist at Lehman Brothers, a US investment bank with financial links to Formula One. The US Commissioner is Director of the Global Road Safety Forum, an organization funded by the FIA and one of the 'implementation partners' that the Commission works with. The Commission's Patron is Prince Michael of Kent, a former racing driver, now a member of the British Racing Drivers Club and the Bentley Drivers Club. Lord Robertson himself is Deputy Chairman of the Board of TNK-BP, a Russian oil company. According to the Lords' Register of Interests, which shows that the FIA paid for Robertson to attend the 2006 Monaco Grand Prix, the Commission meets at the races.

Writing in the Guardian for UN Road Safety Week, Schumacher expressed his delight at being part of the 'independent' Commission for Global Road Safety and his optimism for improving road safety in poor countries. ${ }^{4}$ 'In my racing career, I survived some very high speed impacts. I am still alive because the sport's governing body designed a system where safety is a prime consideration.' Schumacher failed to point out a key difference between the grand prix circuit and roads in poor countries - there are no pedestrians, cyclists or children on the track in motor sport.

Working through the Commission, the FIA and the car lobby have manoeuvred themselves into a leading role in global road safety. They aim to set the policy agenda for road safety, which would give them considerable influence in global transport policy. They do not intent to fund road safety efforts themselves but will dictate how other organizations spend their money, and in particular how development money is spent. Former World Bank President Paul Wolfowitz has already confirmed the Bank's willingness to implement the Commission's recommendations, and UK Secretary for State for International Development Hilary Benn has welcomed the Commission's proposals. ${ }^{1}$

Although in poor countries most people will never own a car and most of the victims of traffic crashes are pedestrians, the Commission has worked hard to ensure that the views of the motoring elites dominate transport 
policy decisions. Unelected, with only token representation from developing nations, the car lobby will dictate how poor countries' governments spend the development loans that their impoverished people will be repaying for decades.

The Commission strongly endorses increased road building in poor countries, claiming that this is essential for achievement of the Millennium Development Goals. The available evidence suggests otherwise. ${ }^{5}$ A review commissioned by the Department of International Development found little evidence that transport infrastructure induces economic growth, and argued that greater emphasis on transportation services, particularly those based around improving public transport and support for cycling, would be more effective. ${ }^{5}$ The review concluded that high levels of private car use are not 'financially, socially, or environmentally sustainable in a developing country context.'

The Commission has, however, drawn attention to the neglect of road safety by the World Bank and recommends that in future $10 \%$ of all road infrastructure funding should be committed to safety. For decades the Bank has directed 'development' loans into road building with little consideration of the resulting increases in road deaths and injuries. ${ }^{6}$ Beneficiaries of this road infrastructure spending include large trans-national corporations, most of which are based in the north, as a result of the reduced costs of raw materials and greater access to cheap labour-cheap because it is unfettered by the health and safety legislation that have pushed up labour costs in the north. ${ }^{6}$ The problem for public health is that the safety policies the car lobby promotes are not particularly effective in preventing injury.

Their favourite policy is road safety education. Despite decades of evaluation research, safety education has never been shown to reduce road injury rates, a point emphasized by the WHO in the World Report on Road Traffic Injury Prevention. ${ }^{7,8}$ Road user education is favoured by the car lobby because it places the responsibility for road traffic injury squarely on the victim and has no impact on industry profits. Its primary purpose is ideological. It sends the message that road space belongs to drivers, and that pedestrians and cyclists must look out or die. This also applies to children, who account for 300,000 of the 1.2 million road deaths each year.

Awareness campaigns are another favourite. The Commission is currently promoting the 'Think Before You Drive' campaign, supported by the Bridgestone Corporation, which reminds drivers to use child seats and seatbelts and to check their tyres. ${ }^{3}$ Sensible suggestions though they may be, such exhortations have no discernable effect on road safety. On the other hand, the campaign may improve Bridgestone's corporate image.

At first sight there appear to be many different stakeholders in the global road safety policy arena, but more careful examination reveals otherwise. In 1999, the World Bank-arguing that a partnership between businesses, NGOs and governments can deliver worthwhile road safety improvements in poor countries - established a Global Road Safety Partnership (GRSP) which includes General Motors, Ford, Daimler Chrysler, Volvo and the drinks multinationals Bacardi-Martini and United Distillers. ${ }^{9}$

The Partnership's commitment to improving road safety has already been questioned. A 2006 report compared the prevalence of certain key words in GRSP reports to their prevalence in a similar report by the WHO. ${ }^{10}$ In the GRSP reports there was a systematic neglect of pedestrians and cyclists. In the WHO report, 'speed limit' occurred 17 times in every 10,000 words; in the Partnership's reports, just once. 'Pedestrian' was used 69 times by the WHO, and 15 times by the Partnership; 'buses' and 'cyclists' were mentioned 13 and 32 times respectively by the WHO but not once by the Partnership.

There are strong ties between the Commission and GRSP. General Motors is represented on the Commission and on the GRSP and David Ward is Secretary of the Commission, Director General of the FIA and on the Executive of the GRSP.

The Commission also has influence within the UN Global Road Safety Collaboration. which was established in 2004 in response to a UN resolution on global road safety. The Collaboration is co-ordinated by WHO, but FIA and GRSP are partners. Although it is reassuring that WHO is co-ordinating the UN Collaboration, most WHO road safety staff are funded by the FIA. Indeed, without FIA funding there would be little WHO road safety activity at all. This is remarkable considering that road traffic crashes are second only to HIV/AIDS as a cause of death in young adults in the developing world. The Global Road Safety Forum, another road safety organization claiming a global remit, is also funded by the FIA.

The FIA has succeeded in raising the profile of road traffic injuries as a global public health problem at the highest political levels. It has also confronted the development banks with the human cost of road building programmes. But there is a downside to putting the car makers and motorist organizations in the driving seat of road safety policy.

Injury is just one of many public health problems arising from increasing motor vehicle use. Transport is $95 \%$ oil dependent and accounts for $14 \%$ of the greenhouse gas emissions that now threaten the sustainability of the planet. A low-carbon, low-energy transportation system with increased levels of walking and cycling and much less car travel is vital in order to avoid catastrophic climate change. ${ }^{11}$ This would also tackle road danger at source.

Urban air pollution, much of which is transport related, causes upwards of 750,000 deaths per year. Reductions in 
the volume and speed of traffic, particularly in cities, could mitigate climate impacts, reduce injury rates and improve air quality. Less traffic would help to raise physical activity levels, thus reducing rates of obesity and diabetes. Reclaiming the streets for walking and cycling is the future of sustainable transport - but this will not be in the interests of the car lobby. ${ }^{11}$

Formula One has a chequered history in public health. In the nineties, it supported the interests of the tobacco industry when it successfully lobbied the UK Government into scrapping its plans to ban tobacco sponsorship in motor sport. ${ }^{12}$ Big tobacco relished its links with Formula One because of its appeal to teenagers. Getting young people hooked was and still is good for profits, even though smoking will kill one in two of those who maintain the habit. Are we to believe that Formula One has now become a force for good in public health? Surely it is time to establish a truly independent Commission for Global Road Safety that will put the daily toll of 3,000 road deaths before any commercial concerns.

Competing interests None declared.

\section{REFERENCES}

1 McMahon K, Ward D. Make Roads Safe. London: Commission for Global Road Safety, 2007

2 Peden M, Scurfield R, Sleet D, et al. World Report on Road Traffic Injury Prevention. Geneva: World Health Organization, 2004.

3 http://www.fiafoundation.com/

4 Schumacher M. One every 30 seconds. The Guardian 23 April 2007

5 Banister D, Wright L. The Role of Transport in Supporting Sub-National Growth. Department for International Development, 2005

6 Roberts I. Injury and globalisation. Injury Prevention 2004;10:65-6

7 Duperrex O, Bunn F, Roberts I. Safety education of pedestrians for injury prevention: a systematic review of randomised controlled trials. BMJ 2002;324:1129

8 Ker K, Roberts I, Collier T, Beyer F, Bunn F, Frost C. Post-licence driver education for the prevention of road traffic crashes: a systematic review of randomised controlled trials. Accid Anal Prev 2005;37:305-13

9 Mohan D, Roberts I. Global road safety and the contribution of big business. BMJ 2001;323:648

10 Roberts I, Wentz R, Edwards P. Car manufacturers and global road safety: a word frequency analysis of road safety documents. Injury Prevention 2006;12:320-2

11 Woodcock J, Banister D, Edwards P, Prentice A, Roberts I. Energy, transport and health. Lancet 2007: in press

12 http://newsvote.bbc.co.uk/1/hi/uk/22550.stm

New From RSM Press...

\section{Developing the Wise Doctor} A Resource for Trainers and Trainees in MMC

\section{Della Fish, Professor of Education (Postgraduate Medicine) King's College London and Linda de Cossart, Consultant Surgeon, Chester}

Developing the Wise Doctor: A Resource for Trainers and Trainees in $M M C$ aims to maximize the potential of trainees in their foundation years and enhance the education of practising doctors.

This book sets out to place firmly in the clinical setting the teaching, assessment and recording of the progress of postgraduate doctors. Challenging activities are presented to engage doctors in exploration of practice, ideals are indicated and ideas offered to provide well-supported development of practical skills.

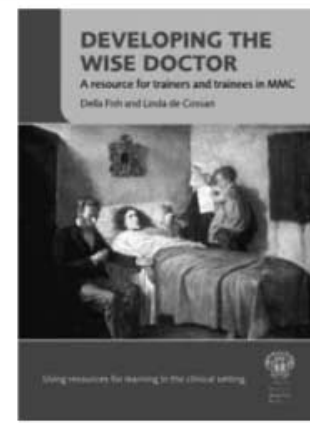

\section{HOW TO ORDER}

Purchase online at www.rsmpress.co.uk or contact Marston Book Services: Tel +44 (0) 1235465500 ; Email ; direct.orders@marston.co.uk

Price: £34.95 • Paperback • July 2007 • 200pp • ISBN: 978-1-85315-618-2 www.rsmpress.co.uk/bkfish.htm 